\title{
ANALISIS PEMILIHAN VENDOR MENGGUNAKAN METODE ANALYTICAL HIERARCHY PROCESS (AHP) (Studi Kasus Pada PT BUKIT ASAM UNIT TARAHAN)
}

\author{
Noneng Nurjanah ${ }^{1}$, Indah Fatmawati ${ }^{2}$ \\ ${ }^{1,2}$ Program Studi D3 Administrasi Logistik, Politeknik Pos Indonesia \\ email: noneng.nurjanah@poltekpos.ac.id
}

\begin{abstract}
Abstrak
PT Bukit Asam (Persero) Tbk Unit Pelabuhan Tarahan merupakan salah satu perusahaan BUMN yang bergerak dalam bidang distribusi batubara. Dalam kelancaran proses produksi PT Bukit Asam Tbk Unit Pelabuhan Tarahan membutuhkan vendor-vendor yang berguna membantu kelancaran produksi. PT Bukit Asam Tbk menggunakan cara pelelangan untuk proses pengadaan, pemilihan vendor menggunakan cara tersebut memerlukan waktu yang cukup lama dengan tahapan yang cukup panjang mulai dari bagian pengadaan membuat permintaan barang yang dibutuhkan kepada vendor lalu dari proses tersebut akan mendapatkan vendor dengan harga yang sesuai. Salah satu metode yang bisa digunakan untuk pemilihan vendor adalah metode Analytical Hierarchy Process (AHP). Penelitian ini bertujuan untuk memilih vendor terbaik dengan cara menyeleksi vendor berdasarkan kriteria dan subkriteria yang sesuai dengan menggunakan metode Analytical Hierarchy Process (AHP). Hasil dari penilaian ini tingkat kepentingan kriteria dalam pemilihan supplier menghasilkan skala prioritas/bobot sebagai berikut: prioritas I cost $(0,470)$, prioritas II quality $(0,370)$, prioritas III delivery $(0,012)$, serta service yaitu $(0,004)$. Dari hasil penilaian tingkat kepentingan alternatif dalam pemilihan supplier menghasilkan skala prioritas/bobot sebagai berikut: prioritas I PT Astraf Tri Manunggal (0,500), prioritas II PT Arta Nusa (0,223), prioritas III PT Branjangan Putra Utama $(0,216)$.
\end{abstract}

Kata Kunci: Pemilihan Vendor, Metode Analytical Hierarchy Process (AHP), Kriteria Pemilihan.

\section{PENDAHULUAN}

Di era globalisasi seperti saat ini selain memunculkan perkembangan di bidang teknologi juga semakin banyak perusahaan dan bisnis baru yang bermunculan. Hal ini menimbulkan persaingan yang semakin ketat antara pelaku bisnis. Perusahaan yang dapat memadukan dengan baik antara strategi, teknologi, dan sumber daya yang ada, akan dapat bertahan dengan baik dalam persaingan dengan perusahaan yang bergerak di bidang industri yang sama. Pada dasarnya setiap perusahaan mempunyai orientasi bisnis yang sama; yaitu menghasilkan keuntungan yang maksimal dengan meminimalkan biaya yang dikeluarkan. Hal tersebut dapat terwujud dengan pemilihan vendor atau pemasok yang tepat.

Vendor merupakan salah satu bagian dari supply chain yang penting dan akan mempengaruhi kinerja perusahaan. Oleh karena itu, perusahaan perlu menilai vendor atau pemasok secara cermat dan tepat. Pemilihan vendor merupakan kegiatan strategis, terutama apabila vendor tersebut akan memasok item yang penting dan akan digunakan dalam jangka panjang. Sehingga untuk kelancaran proses produksi harus mengetahui terlebih dahulu kriteria-kriteria yang terpenting untuk dijadikan tolak ukur dalam pemilihan vendor.

PT Bukit Asam (Persero) Tbk Unit Tarahan atau disebut juga dengan PTBA merupakan salah satu perusahaan BUMN yang bergerak dalam bidang distribusi batubara yang berpusat di Tanjung enim, Sumatera Selatan. PT Bukit Asam (Persero) Tbk adalah perusahaan milik negara yang bertujuan mengembangkan usaha pertambangan nasional khususnya batubara. Dalam kelancaran proses produksi PT Bukit Asam Tbk Unit Tarahan membutuhkan vendorvendor yang berguna membantu kelancaran produksi.

Permasalahan yang dihadapi oleh PT Bukit Asam Unit Tarahan adalah proses pemilihan vendor sparepart rotary car dumper masih 
menggunakan metode pelelangan, pemilihan vendor menggunakan cara tersebut memerlukan waktu yang cukup lama kurang lebih sampai 3 bulan dengan tahapan yang cukup panjang mulai dari bagian pengadaan membuat permintaan barang yang dibutuhkan kepada vendor lalu dari proses tersebut akan mendapatkan vendor dengan harga yang sesuai. Setelah proses lelang, perusahaan akan mendata vendor terpilih untuk meninjau barang penawaran apakah sesuai dengan standar perusahaan, jika tidak sesuai maka perusahaan akan menolak dan jika telah sesuai vendor akan dihubungi untuk melakukan rapat dan negosisasi anatara kedua belak pihak. Perusahaan harus melakukan pemilihan vendor yang sesuai dengan kriteria yang dibutuhkan oleh perusahaan (Setyorini, (2012).

Kriteria pemilihan vendor akan berdampak terhadap kualitas barang yang akan di pasok, sehingga akhirnya berpengaruh terhadap produktivitas perusahaan, hal ini dikarenakan rotary car dumper merupakan salah satu faktor terpenting dalam proses produksi pengangkutan batu bara di PT. Bukit Asam unit Tarahan. Untuk mendapatkan vendor yang sesuai dengan kebutuhan PT Bukit Asam Unit Tarahan harus mengetahui terlebih dahulu kriteria-kriteria terpenting yang dapat dijadikan tolak ukur dalam pemilihan vendor.

Penelitian ini bertujuan untuk memilih vendor terbaik dengan cara menyeleksi vendor berdasarkan kriteria dan subkriteria yang sesuai dengan menggunakan metode Analytic Hierarchy Process (AHP). Metode ini digunakan untuk memecahkan persoalan yang kompleks dengan menstruktur suatu hirarki kriteria, pihak yang berkepentingan, hasil dengan menarik berbagai pertimbangan sebagai bobot atau prioritas (Mubarok, 2017). Keuntungan dari metode AHP dalam pemecahan persoalan dan pengambilan keputusan antara lain adalah:

1. Kesatuan: AHP memberi satu model tunggal yang mudah dimengerti, luwes untuk aneka ragam persoalan tak terstruktur.
2. Kompleksitas: AHP memadukan ancangan deduktif dan ancangan berdasarkan sistem dalam memecahkan persoalan kompleks.

3. Saling ketergantungan: AHP dapat menangani saling ketergantungan elemenelemen dalam suatu sistem dan tidak memaksakan pemikiran linier

4. Penyusunan hirarki: AHP mencerminkan kecenderungan alami pikiran untuk memilah elemen-elemen suatu sistem dalam berbagai tingkat berlainan dan mengelompokkan unsur yang serupa dalam setiap tingkat.

5. Pengukuran: AHP memberi suatu skala untuk mengukur hal-hal dan wujud suatu model untuk menetapkan prioritas (Rahmayani, 2010).

\section{METODOLOGI}

Tahapan-tahapan penelitian yang dilakukan dalam penyusunan laporan Tugas Akhir, adapun tahapan tersebut sebagai berikut :

1. Studi Pustaka dan Studi Literatur Melakukan studi lapangan dan studi literatur. Mendapatkan data yang dibutuhkan penulis dengan studi literatur yaitu mengumpulkan informasi dan data seperti buku, catatan, artikel, dan sebagainya serta studi lapangan berupa pengumpulan data secara langsung ke lapangan seperti observasi, wawancara dan sebagainya. Pada penelitian ini peneliti akan meneliti PT Bukit Asam Unit Tarahan yang bergerak di bidang ekpor-impor batubara.

2. Perumusan Masalah

Setelah menentukan objek penelitian, peneliti selanjutnya menentukan perumusan masalah yang akan disusun berupa pertnyaan-pertanyaan dan akan menjadi dasar penelitian ini.

3. Menentukan Tujuan Penelitian

Menentukan apa tujuan dan manfaat penelitian dengan rumusan masalah yang telah diambil.

4. Mengumpulkan Data

Data yang didapat dari hasil studi literatur dan studi lapangan dikumpulkan menjadi satu. 
5. Pengolahan Data

Pada tahap ini, peneliti mengolah hasil dari penyebaran kuisioner yang didapatkan, yang nantinya digunakan sebagai data untuk pengambilan keputusan.

6. Analisis

Analisis dari hasil pengolahan data apakah dengan metode tersebut dapat menyelesaikan masalah atau tidak.

7. Kesimpulan dan saran

Pada kesimpulan dan saran didapati hasil pengolahan data yaitu penentuan vendor manakah yang terbaik untuk memasok sparepart rotary car dumper di PT Bukit Asam Unit Tarahan. Pada kesimpulan ini didapati juga kekurangan dan kelebihan dalam penelitian sehingga nantinya dijadikan sebagai saran.

Dalam pemecahan suatu masalah diperlukannya data pendukung yang berhubungan dengan masalah yang akan dipecahkan dan untuk proses lebih lanjut. Tujuan dari penelitian ini adalah memilih vendor sparepart rotary car dumper berdasarkan kriteria-kriteria yang dibutuhkan. Pengolahan data ini menggunakan metode Analytical Hierarchy Proses (AHP) yang diperoleh dari hasil rekapitulasi kuesioner yang diisi oleh responden.

Dalam metode AHP, kriteria biasanya disusun dalam bentuk hirarki. Kriteria dan subkriteria dalam penelitian ini merupakan kriteria dan subkriteria yang diperoleh dari studi literatur. Masalah pemilihan supplier pada PT Bukut Asam Unit Tarahan disusun dalam tiga level hirarki seperti pada gambar IV.1. Level 0 merupakan tujuan yaitu memilih supplier terbaik (optimal), level pertama merupakan kriteria dalam pemilihan supplier, level 2 merupakan subkriteria yang merupakan penjabaran dari level pertama (kriteria), sedangkan level 3 merupakan alternatif, supplier mana yang sebaiknya dipilih.

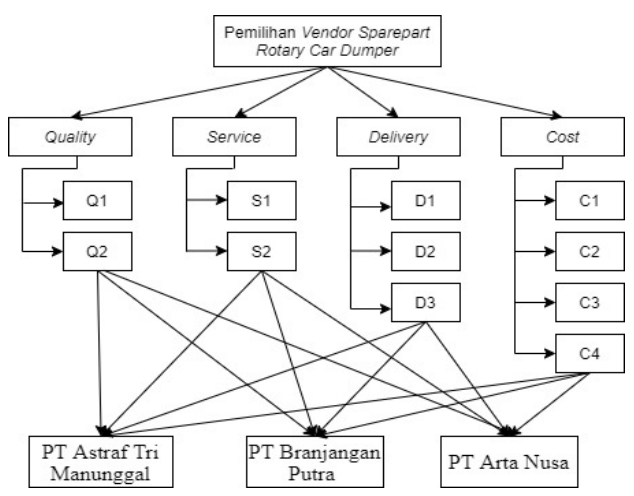

Gambar 2 Struktur Hirarki Pemilihan Vendor

Membuat matriks perbandingan berpasangan yang menggambarkan kontribusi relatif pengaruh setiap elemen terhadap masing-masing tujuan kriteria yang setingkat di atasnya. Dalam pengolahan data pada penelitian ini, langkah awal dimulai dengan menghitung Geometric Mean, karena penulis mengambil empat responden sebagai pengisi penilaian kuisioner dan hasil penilaian seluruh responden berbeda-beda, maka pada tahap ini penulis melakukan perhitungan Geometric Mean yaitu untuk mengambil nilai rata-rata dari keseluruhan responden tersebut.

Nilai yang dihasilkan dari perhitungan Geometric Mean merupakan input nilai perbandingan antar elemen dalam penelitian ini. Rumus dari Geometric Mean adalah:

$$
A_{i j}=\left(Z_{1} Z_{2} \ldots Z_{n}\right)^{1 / n}
$$

Setelah masing-masing kriteria dan alternatif didapatkan kemudian dilakukan sintesis untuk mendapatkan bobot alternatif secara keseluruhan dari kriteria yang ada. Sebelumnya bobot/prioritas lokal (local priority) harus dicari nilai globalnya (global priority) terlebih dahulu. Untuk mendapatkan global priority dengan cara mengalikan local priority dengan prioritas level di atasnya (parent criterion). Secara detail, hasil pembobotan kriteria dan alternatif dapat dilihat dalam tabel IV.40 dibawah ini: 
Tabel 3 Prioritas Global

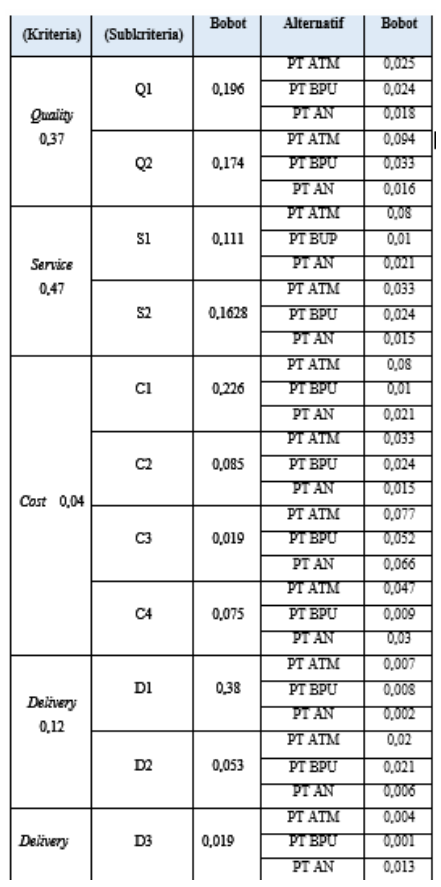

Setelah global priority didapatkan, bobot masingmasing alternatif secara keseluruhan dapat dihitung dengan menjumlahkan semua bobot keseluruhan (global priority) pada masing-masing vendor, hasilnya ditunjukkan pada tabel IV.41 di bawah ini:

Tabel 4 Prioritas Global (Global Priority) Vendor

\begin{tabular}{|c|c|c|}
\hline Alternatif & Bobot & Prioritas \\
\hline PT ATM & 0,500 & I \\
\hline PT BPU & 0,216 & III \\
\hline PT AN & 0,223 & II \\
\hline
\end{tabular}

Tabel 4 di atas menunjukkan bahwa secara keseluruhan, PT Astraf Tri Mnaunggal dengan nilai bobot 0,500 merupakan prioritas pertama untuk dipilih sebagai vendor spareparts rotary car dumper pada PT Bukit Asam Unit Tarahan. Prioritas kedua adalah PT Arta Nusa dengan nilai bobot 0,223 , sedangkan prioritas terakhir adalah PT Branjangan Putra Utama dengan nilai bobot 0,198 .

d. Consistensi Ratio (CR) Penilaian Responden Pengukuran konsistensi ini dimaksudkan untuk melihat ketidak konsistenan respon yang diberikan responden. Sehingga jika tidak konsisten, maka pengisian nilai-nilai pada matriks berpasangan pada unsur kriteria maupun alternatif harus diulang. Tabel IV.49 berikut ini menunjukkan nilai konsistensi rasio (CR) dari penilaian responden:

Tabel 5 Consistensi Ratio (CR) Penilaian Responden

\begin{tabular}{|l|c|c|}
\hline \multicolumn{1}{|c|}{ Perbandingan Berpasangan } & CR & Kenterangan \\
\hline Antar Kriteria (Level 1) & 0,051 & Konsisten \\
\hline Antar Subkriteria Quality & 0,000 & Konsisten \\
\hline Antar Subkriteria Service & 0,000 & Konsisten \\
\hline Antar Subkriteria Cost & 0,089 & Konsisten \\
\hline Antar Subkriteria Delivery & 0,085 & Konsisten \\
\hline Antar Alternatif Vendor Terhadap Subkriteria Q1 & 0,027 & Konsisten \\
\hline Antar Alternatif Vendor Terhadap Subkriteria Q2 & 0,072 & Konsisten \\
\hline Antar Alternatif Vendor Terhadap Subkriteria S1 & 0,020 & Konsisten \\
\hline Antar Alternatif Vendor Terhadap Subkriteria S2 & 0,030 & Konsisten \\
\hline Antar Alternatif Vendor Terhadap Subkriteria C1 & 0,063 & Konsisten \\
\hline Antar Alternatif Vendor Terhadap Subkriteria C2 & 0,070 & Konsisten \\
\hline Antar Alternatif Vendor Terhadap Subkriteria C3 & 0,040 & Konsisten \\
\hline Antar Alternatif Vendor Terhadap Subkriteria C4 & 0,015 & Konsisten \\
\hline Antar Alternatif Vendor Terhadap Subkriteria D1 & 0,090 & Konsisten \\
\hline Antar Alternatif Vendor Terhadap Subkriteria D2 & 0,050 & Konsisten \\
\hline Antar Alternatif Vendor Terhadap Subkriteria D3 & 0,000 & Konsisten \\
\hline
\end{tabular}

Tabel 5 di atas menunjukkan bahwa semua penilaian responden konsisten, dan tidak perlu diulang lagi.

\section{PEMBAHASAN}

Dari hasil analisis AHP di atas, kriteria yang paling berpengaruh dalam pemilihan vendor pada $\mathrm{PT}$ Bukit Asam Unit Tarahan adalah kriteria cost, quality, delivery dan service.

Kriteria quality menempati urutan pertama dalam pemilihan vendor dengan dengan bobot 0,47, selanjutnya prioritas kedua yaitu kriteria quality dengan bobot 0,37 , prioritas ketiga kriteria delivery dengan bobot 0,12 , prioritas selanjutnya service dengan bobot 0,04 . Dengan tingginya nilai bobot cost menunjukkan bahwa PT. Bukit Asam Unit Tarahan memprioritaskan cost untuk pengadaan barang yang akan digunakan.

Kriteria cost yang digunakan dalam penelitian ini mencakup empat subkriteria yaitu Kepantasan harga dengan kualitas barang (C1), Kemampuan memberikan diskon pada pemesanan dalam jumlah tertentu (C2), Jumlah pembelian minimum (C3), dan Kepantasan harga dengan kualitas barang yang dihasilkan dibandingkan dengan harga dari kompetitor lain (C4). Kepantasan harga dengan kualitas barang $(\mathrm{C} 1)$ menempati prioritas pertama 
dalam memilih vendor dengan nilai bobot 0,48 . Prioritas kedua adalah Kemampuan memberikan diskon pada pemesanan dalam jumlah tertentu (C2) dengan nilai bobot 0,32 . Prioritas ketiga adalah subkriteria Ketepatan Kepantasan harga dengan kualitas barang yang dihasilkan dibandingkan dengan harga dari kompetitor lain (C4) dengan nilai bobot 0,16 , dan Prioritas terakhir adalah subkriteria Jumlah pembelian minimum (C3) dengan nilai bobot 0,04 . Dengan tingginya nilai bobot subkriteria kepantasan harga dengan kualitas barang menunjukkan bahwa PT. Bukit Asam Unit Tarahan memprioritaskan kesesuaian harga dengan kualitas untuk pengadaan barang yang akan digunakan.

Pada subkriteria kepantasan harga dengan kualitas barang (C1), PT Astraf Tri Manunggal merupakan prioritas pertama untuk dipilih sebagai vendor menurut responden dengan nilai bobot 0,72 . Sedangkan prioritas kedua adalah PT Arta Nusa dengan nilai bobot 0,19 dan prioritas terakhir yaitu PT Branjangan Putra Utama dengan nilai bobot 0,09 .

Pada subkriteria Kemampuan memberikan diskon pada pemesanan dalam jumlah tertentu (C2), PT Astraf Tri Manunggal merupakan prioritas pertama untuk dipilih sebagai vendor menurut responden dengan nilai bobot 0,20 . Sedangkan prioritas kedua adalah PT Branjangan Putra Utama dengan nilai bobot 0,15 dan prioritas terakhir yaitu PT Arta Nusa dengan nilai bobot 0,09 .

Pada subkriteria Jumlah pembelian minimum (C3), PT Astraf Tri Manunggal merupakan prioritas pertama untuk dipilih sebagai vendor menurut responden dengan nilai bobot 0,34. Sedangkan prioritas kedua adalah PT Arta Nusa dengan nilai bobot 0,29 dan prioritas terakhir yaitu PT Branjangan Putra Utama dengan nilai bobot 0,23. Pada subkriteria Kepantasan harga dengan kualitas barang yang dihasilkan dibandingkan dengan harga dari kompetitor lain (C4), PT Astraf Tri Manunggal merupakan prioritas pertama untuk dipilih sebagai vendor menurut responden dengan nilai bobot 0,55 . Sedangkan prioritas kedua adalah PT Arta Nusa dengan nilai bobot 0,35 dan prioritas terakhir yaitu PT Branjangan Putra Utara dengan nilai bobot 0,10 .

Kriteria quality menempati urutan kedua dalam pemilihan vendor dengan nilai bobot 0,37 . Dalam penelitian ini, terdapat dua subkriteria pada kriteria quality yaitu, kesesuaian barang dengan spesifikasi yang sudah ditetapkan (Q1) dan kondisi barang tidak cacat (Q2).

Subkriteria Kesesuaian barang dengan spesifikasi yang sudah ditetapkan (Q1) menempati prioritas pertama dalam memilih vendor dengan nilai bobot 0,53. Prioritas kedua adalah Kondisi barang tidak cacat (Q2) dengan nilai bobot 0,47 .

Pada subkriteria Kesesuaian barang dengan spesifikasi yang sudah ditetapkan (Q1), PT Asraf Tri Manunggal merupakan prioritas pertama untuk dipilih sebagai vendor menurut responden dengan nilai bobot 0,13 . Sedangkan prioritas kedua adalah PT Branjangan Putra Utama dengan nilai bobot 0,12 , dan prioritas terakhir yaitu PT AN dengan nilai bobot 0,09 .

Pada subkriteria Kondisi barang tidak cacat (Q2), PT Asraf Tri Manunggal merupakan prioritas pertama untuk dipilih sebagai vendor menurut responden dengan nilai bobot 0,54. Sedangkan prioritas kedua adalah PT Branjangan Putra Utama dengan nilai bobot 0,19 , dan prioritas terakhir yaitu PT Arta Nusa dengan nilai bobot 0,09 .

Kriteria delivery menempati urutan ketiga dalam pemilihan vendor dengan nilai bobot 0,012. Pada kriteria delivery terdapat tiga subkriteria yaitu Kemampuan dalam hal penanganan sistem transportasi (D1), Kemampuan untuk mengirimkan barang sesuai dengan tanggal yang telah disepakati (D2), dan Ketepatan spesifikasi barang yang dikirim terhadap order pembelian (D3).

Subkriteria kemampuan untuk mengirimkan barang sesuai dengan tanggal yang telah disepakati (D2) menempati prioritas pertama dalam memilih vendor dengan nilai bobot 0,44. Prioritas selanjutnya adalah kemampuan dalam hal penanganan sistem transportasi (D1) dengan nilai bobot 0,32 , dan prioritas terakhir adalah subkriteria Ketepatan spesifikasi barang yang dikirim terhadap order pembelian (D3) dengan nilai bobot 0,16.

Pada subkriteria Kemampuan dalam Hal Penanganan Sistem Transportasi (D1), PT Branjangan Putra Utama dengan nilai bobot 0,40 merupakan prioritas pertama untuk dipilih. Sedangkan prioritas kedua adalah PT Astraf Tri Manunggal dengan nilai bobot 0,38 dan prioritas 
terakhir yaitu PT Arta Nusa dengan nilai bobot 0,12 .

Pada subkriteria Kemampuan untuk mengirimkan barang sesuai dengan tanggal yang telah disepakati (D2), PT BPU dengan nilai bobot 0,40 merupakan prioritas pertama untuk dipilih. Sedangkan prioritas kedua adalah PT ATM dengan nilai bobot 0,38 dan prioritas terakhir yaitu PT AN dengan nilai bobot 0,12 .

Pada subkriteria Ketepatan spesifikasi barang yang dikirim terhadap order pembelian (D3), PT AN dengan nilai bobot 0,70 merupakan prioritas pertama untuk dipilih. Sedangkan prioritas kedua adalah PT ATM dengan nilai bobot 0,23 dan prioritas terakhir yaitu PT BPU dengan nilai bobot 0,12 .

Kriteria service menempati urutan keempat dalam pemilihan vendor dengan nilai bobot 0,004 . Pada kriteria delivery terdapat dua subkriteria yaitu Kemudahan untuk dihubungi (S1) dan Kemampuan untuk memberikan informasi secara jelas dan mudah untuk dimengerti (S2).

Pada subkriteria Kemudahan untuk dihubungi (S1), PT AN dengan nilai bobot 0,48 merupakan prioritas pertama untuk dipilih. Sedangkan prioritas kedua adalah PT ATM dengan nilai bobot 0,41 dan prioritas terakhir yaitu PT BPU dengan nilai bobot 0,11 .

Pada subkriteria Kemampuan untuk memberikan informasi secara jelas dan mudah untuk dimengerti (S2), PT ATM dengan nilai bobot 0,30 merupakan prioritas pertama untuk dipilih. Sedangkan prioritas kedua adalah PT BPU dengan nilai bobot 0,10 dan prioritas terakhir yaitu PT AN dengan nilai bobot 0,09 .

Secara keseluruhan, berdasarkan kriteria-kriteria dan subkriteria dalam pemilihan vendor, PT Astraf Tri Manunggal dinilai sebagai vendor terbaik dengan nilai bobot 0,500 . Selanjutnya adalah PT Arta Nusa dengan nilai bobot 0,223 dan PT Branjangan Putra Utama dengan nilai bobot 0,216. Hasil ini menunjukkan bahwa secara keseluruhan vendor terbaik yang akan dipilih oleh perusahaan untuk dijadikan sebagai rekanan/mitra jangka panjang adalah PT Astraf Tri Manunggal karena secara keseluruhan vendor ini memiliki nilai paling tinggi dibandingkan dengan dua vendor yang lain.

\section{KESIMPULAN}

Berdasarkan tujuan penelitian dan hasil penelitian di atas maka dapat disimpulkan beberapa hal berikut ini:

1. Kriteria yang paling berpengaruh dalam pemilihan vendor sparepart rotary car dumper pada PT Bukit Asam Unit Tarahan adalah kriteria cost dengan bobot $(0,470)$. Prioritas kedua yang berpengaruh adalah kriteria quality dengan bobot $(0,370)$. Prioritas ketiga adalah kriteria delivery dengan bobot $(0,120)$, sedangkan prioritas keempat adalah kriteria service $(0,004)$. Subkriteria dalam pemilihan vendor secara berturut-turut dari prioritas pertama sampai prioritas terakhir adalah sebagai berikut: Kesesuaian barang dengan spesifikasi yang sudah ditetapkan dengan bobot $(0,530)$; Kepantasan harga dengan kualitas barang dengan bobot $(0,480)$; Kondisi barang tidak cacat dengan bobot $(0,470)$; Kemampuan untuk mengirimkan barang sesuai dengan tanggal yang telah disepakati dengan bobot $(0,440)$; Kemampuan untuk memberikan informasi secara jelas dan mudah untuk dimengerti dengan bobot $(0,440)$; Kemampuan memberikan diskon pada pemesanan dalam jumlah tertentu dengan bobot (0,320); Kemampuan dalam hal penanganan sistem transportasi dengan bobot $(0,320)$; Kemudahan untuk dihubungi dengan bobot $(0,300)$; Kepantasan harga dengan kualitas barang yang dihasilkan dibandingkan dengan harga dari kompetitor lain dengan bobot (0,160); Ketepatan spesifikasi barang yang dikirim terhadap order pembelian dengan bobot $(0,160)$; Jumlah pembelian minimum dengan bobot $(0,004)$.

2. Berdasarkan kriteria-kriteria dan subkriteria dalam pemilihan vendor, secara keseluruhan PT Asraf Tri Manunggal dinilai sebagai vendor terbaik dengan bobot $(0,500)$. Prioritas selanjutnya adalah PT Arta Nusa dengan nilai bobot $(0,223)$ dan prioritas terakhir adalah PT Branjangan Putra Utama dengan nilai bobot $(0,216)$. Hal ini menunjukkan bahwa secara keseluruhan sparepats rotary car dumper bagi 
perusahaan untuk dijadikan sebagai rekanan/mitra jangka panjang adalah $\mathrm{PT}$. Astraf Trimanunggal karena secara keseluruhan vendor ini memiliki nilai paling tinggi dibandingkan dengan dua vendor yang lain.

\section{REFERENSI}

Mubarok, A. E. (2017). Penerapan Metode Analytical Hierarchy Process Dalam Sistem.

Putri, C. F. (2012). Pemilihan Supplier Bahan Baku Pengemas Dengan Metode Ahp (Analytical Hierarchy Process). Widya Teknika.

Rahmayanti, R. (2010). Analisis Pemilihan Supplier Menggunakan Metode.

Setyorini, S. W. ((2012)). Penentuan kriteria terpenting dalam pemilihan supplier di family business dengan menggunakan pendekatan analytic hierarchy process (AHP)(Studi kasus pada Perusahaan Garmen PT. X).

Saaty, Thomas L. (1994). Fundamentals of Decision Making and Priority Theory with the Analytic Hierarchy Process. RWS Publications : Pittsburgh USA.

Wulandari, N. (2014). Perancangan Sistem Pendukung Keputusan Pemilihan Supplier di PT. Alfindo Dengan Metode Analytical Hierarchy Process (AHP). Jurnal Sistem Informasi. 